\title{
Quantification of silver nanoparticle interactions with yeast Saccharomyces cerevisiae studied using single-cell ICP-MS
}

\author{
Lindsey Rasmussen ${ }^{1} \cdot$ Honglan Shi ${ }^{1,2,3}$ (1) $\cdot$ Wenyan Liu ${ }^{1,3} \cdot$ Katie B. Shannon ${ }^{4}$
}

Received: 4 November 2021 / Revised: 22 December 2021 / Accepted: 28 January 2022 / Published online: 4 February 2022

(c) Springer-Verlag GmbH Germany, part of Springer Nature 2022

\begin{abstract}
Silver nanoparticles (AgNPs) have been used in many fields due to their anticancer, antimicrobial, and antiviral potential. Single-cell ICP-MS (SC-ICP-MS) is an emerging technology that allows for the rapid characterization and quantification of a metal analyte across a cell population in a single analysis. In this study, a new rapid and sensitive SC-ICP-MS method was developed to quantitatively study the interactions of AgNPs with yeast Saccharomyces cerevisiae. The method can quantify the cell concentration, silver concentration per cell, and profile the nanoparticle distribution in a yeast cell population. AgNP dosing time, concentration, and AgNP size were quantitatively evaluated for their effects on AgNP-yeast cell interactions. The results showed that the initial uptake of AgNPs was rapid and primarily driven by the mass of Ag per cell. The optimal dosing particle concentrations for highest uptake were approximately 1820, 1000, and $300 \mathrm{AgNPs} / \mathrm{cell}$ for 10, 20, and $40 \mathrm{~nm}$ AgNPs, respectively. Furthermore, this study also validated a washing method for the application to a microorganism for the first time and was used to quantitatively determine the amount of cell surface-adsorbed AgNPs and intracellular AgNPs. These results indicated that the mass (Ag in ag/cell) ratios of intracelluar vs cell surface-adsorbed AgNPs were similar for different AgNP sizes. This high throughput and ultrasensitive SC-ICP-MS method is expected to have many potential applications, such as optimization of methods for green synthesis of AgNPs, nanotoxicity studies, and drug delivery. This is the first quantification study on the interactions of AgNPs and S. cerevisiae using SC-ICP-MS.
\end{abstract}

Keywords Silver nanoparticle $\cdot$ Yeast cell $\cdot$ Single-cell ICP-MS · Uptake of AgNP by yeast cell $\cdot$ Surface-adsorbed AgNP . Intracellular AgNP

\section{Introduction}

The incorporation of nanotechnology into daily life is growing with applications in commercial products, antibacterial materials, and drug delivery [1-4]. Better understanding of the interaction mechanisms between nanoparticles and

Honglan Shi

honglan@mst.edu

1 Department of Chemistry, Missouri University of Science and Technology, 400 West 11th Street, Rolla, MO 65409, USA

2 Center for Single Nanoparticle, Single Cell, and Single Molecule Monitoring (CS3M), Missouri University of Science and Technology, Rolla, MO 65409, USA

3 Center for Research in Energy and Environment, Missouri University of Science and Technology, Rolla, MO, USA

4 Biological Sciences, Missouri University of Science and Technology, Rolla, MO 65409, USA cells is becoming more important. The effects of nanoparticle waste on the environment such as potential toxic effects on aquatic and plant organisms or air quality are an area of research with many unknowns $[1,5]$. Research and development of "green manufacturing methods" using fungi, bacterial, and plant substrates for nanotechnology production to reduce the environmental impact of the sector has also grown substantially $[3,6,7]$. The exact modes of antibacterial action of nanoparticles on cells are still not fully defined as they can differ based on the cell type, nanoparticle type, and experimental conditions $[5,8,9]$. In drug delivery, the percentage of nanoparticle-based drug that is actually delivered to the target tumor location can be less than $1 \%$, showing that there is still substantial room for optimization of these techniques [10]. More recently, nanoparticles, including silver nanoparticles (AgNPs), have been shown to neutralize COVID-19 viruses [11] and have also been applied to the masks and air filters to inactivate Coronaviruses [12]. Therefore, with the growth of 
the nanotechnology sector and research into these various areas, there has been concurrent development of analytical techniques to facilitate the advancement of nanotechnology. There is no single technology that can fully characterize nanoparticle interactions with a biological system or the environment. Various combinations of different techniques are the practical approaches currently. Spectroscopy, various types of electron microspectroscopic images, and ICP-MS are the major analytical techniques that have been used in this field [13-15]. ICP-MS-based analytical techniques for the detection of metal content in cells [16] such as singlecell (SC) ICP-MS [17-22], including SC-ICP-TOF-MS (also referred to as mass cytometry) [23, 24], LA-ICP-MS [25-28], and microfluidic device-coupled ICP-MS [29] are advancing very rapidly to study nanoparticle and cell interaction mechanisms, nanotoxicity, drug development, and delivery at the single-cell level. More recently, an ICP-OES method was also used for silver nanoparticle speciation after sequential extraction of the solid materials [30]. Comprehensive reviews and comparisons of different techniques and their applications in single-cell analyses have been reviewed extensively [13, 14, 31-35].

SC-ICP-MS is a cutting-edge technology that can help yield insights into the gaps of nanoparticle knowledge as has been previously described [16, 20-22]. Conventional ICP-MS analysis of the metal content in cells is limited to measurements of the average amount per cell in a cell population after acid digestion [16, 21]. The key advantage of the SC-ICP-MS technology is that it rapidly provides the distribution of the metal content within a cell population, allowing for the discrimination of differences due to cell heterogeneity $[16,18,19,21]$. The analysis is time-resolved, uses a low flow rate high-efficiency nebulizer, and each cell is detected as a single pulse signal. The intensity of the pulse signal is proportional to the mass of the element in each individual cell, and the frequency of the pulse signals is proportional to the cell concentration. This allows for the quantitation of metal ion uptake, metal-based nanoparticle uptake or intrinsic metal, such as $\mathrm{Zn}$ or $\mathrm{Cu}$, concentration measurement in each cell $[18,19,21]$. In addition, the single-cell sampling setup and the software can be easily implemented (in comparison to purchasing a new instrument) into an existing ICP-MS in a laboratory, with minimal cost and operator training required for operation. Though it is still at the infancy step of the SC-ICP-MS technology development, it is expected that this technique will advance very quickly and will highly benefit research and applications, especially in the fields of nanomedicine, drug delivery, green synthesis of nanoparticles, and nanotoxicity study.

AgNP is one of the most broadly used nanomaterials. It is particularly popular in agrochemicals (pesticides, insecticides, fungicides, fertilizer), nanomedicines, and drug delivery. Its green synthesis is also an active research field.
Yeast Saccharomyces $(S$.$) cerevisiae cells have been used$ for AgNP green synthesis [36-38] and is also a popular cell type for nanomaterial-cell interaction mechanism study and other nanotoxicity studies [39-41]. It is reported that AgNPs readily adhere to the yeast cell wall and are also taken up intracellularly [15, 42-44]. Chen et al. [37] also demonstrate how $S$. cerevisiae coupled to AgNPs could be used to remove heavy metals from wastewater while also providing antibacterial functions. While the majority of previous toxicity research focuses on evaluating the dosing-toxicity relationship between nanoparticles and cells, comparisons between studies are difficult due to variation in experimental variables such as limited datapoints per study, measurement methods, nanoparticle properties, experimental conditions, and cell type [13, 45, 46]. Kettler et al. demonstrated that even differences in the dosing medium used in a study could have significant effects on the observed uptake [9]. Although studies have reported the interactions of AgNPs with yeast cells $[15,42-44]$ and the mechanism with different techniques, a rapid and highly sensitive SC-ICP-MS quantification method is still lacking and needed for quantitative and comprehensive study of the broadly used AgNPs and yeast cells.

The objectives of this study are to develop a rapid, ultrasensitive SC-ICP-MS quantification method to study AgNP and yeast cell interactions, to quantitatively measure the amount of cell surface adsorbed and intracellular AgNPs, and to optimize conditions of AgNP uptake by yeast cells. This method can be used to support the variety of applications stated above for this common NP-cell model. The method is expected to benefit the potential application of S. cerevisiae as a green synthesis substrate, cell model for nanotoxicity, or drug delivery research, etc. To the authors' best knowledge, this is the first quantification study on the interactions of AgNPs and S. cerevisiae under different conditions using SC-ICP-MS.

\section{Materials and methods}

\section{Materials}

Citrate-stabilized AgNP standard suspensions (10, 20, 40,70 , and $100 \mathrm{~nm}$ at $0.02 \mathrm{mg} / \mathrm{mL}$ ) were purchased from Nanocomposix (San Diego, CA, USA). S. cerevisiae (S288c) was obtained from ATCC. The cell strain was BY4743 with genotype $M A T \mathrm{a} / \alpha$ his $3 \Delta 1 /$ his $3 \Delta 1$ leu $2 \Delta 0 /$ leu $2 \Delta 0$ LYS2/lys $2 \Delta 0$ met $15 \Delta 0 / M E T 15$ ura $3 \Delta 0 /$ ura $3 \Delta 0$. Sodium hydroxide; sodium thiosulfate $\left(\mathrm{Na}_{2} \mathrm{~S}_{2} \mathrm{O}_{3} \cdot 5 \mathrm{H}_{2} \mathrm{O}\right)$; and YPD medium containing tryptone, yeast extract, and dextrose were obtained from Fisher Scientific (Fair Lawn, NJ, USA). 2-(N-Morpholino)ethanesulfonic acid (MES) hydrate, ethylenediaminetetraacetic acid (EDTA), 
and potassium ferricyanide $\left(\mathrm{K}_{3} \mathrm{Fe}(\mathrm{CN})_{6}\right.$ were purchased from Sigma-Aldrich (St. Louis, MO, USA). Dextrose was purchased from MP Biomedicals (Solon, OH, USA). Ultrapure water $(18.2 \mathrm{M} \Omega-\mathrm{cm})$ was produced by an Elix-3 water purification system from Millipore (Billerica, MA, USA). EQ four-element calibration beads, polystyrene beads $(2.5 \mu \mathrm{m})$ containing known concentrations of the metal elements $\mathrm{Ce}, \mathrm{Eu}, \mathrm{Ho}$, and $\mathrm{Lu}$ in aqueous suspension, were purchased from Fluidigm (San Francisco, CA, USA).

\section{Yeast cell culture}

For each experiment, one colony of yeast cells was cultured in a sterile cell culture flask with $30 \mathrm{~mL}$ of YPD medium $\left(50 \mathrm{~g} / \mathrm{L}\right.$ in ultrapure $\left.\mathrm{H}_{2} \mathrm{O}\right)$ at room temperature on a rotor at 12 rotations per minute for the necessary time. The cells were then sent into log phase by resuspending cells in about $50 \mathrm{~mL}$ of fresh YPD medium, and incubating on the rotor for an additional 1.5-2 $\mathrm{h}$. At the end of this time period, the cell sample was transferred to centrifuge tubes, centrifuged ( $5 \mathrm{~min}$ at $500 \mathrm{~g}$ ), and then washed 3 times using $10 \mathrm{~mL}$ ultrapure $\mathrm{H}_{2} \mathrm{O}$ per wash and recentrifuged after each wash. The samples were centrifuged a fourth time and resuspended in $1 \mathrm{~mL}$ of ultrapure $\mathrm{H}_{2} \mathrm{O}$. All resuspended cell samples were then combined into one vial to make a cell stock suspension. A hemacytometer was used to count the concentration of the cell stock suspension for the subsequent use in the next experimental step.

\section{Single-cell ICP-MS method}

For all experiments, a Nexion300D ICP-MS (PerkinElmer, Shelton, CT), the same sample introduction system and Syngistix Single-Cell Application software used for a previous study of toxic algae treatment by copper-based algaecide (Shen et al. 2019), was utilized. Additionally, a single-cell Micro DX autosampler was added to the system and used for the SC-ICP-MS analysis. ICP-MS parameters, including autosampler specific parameters, are shown in Table $1 .{ }^{107} \mathrm{Ag}$ was monitored for AgNP and cell interaction and ${ }^{64} \mathrm{Zn}$ was monitored as an intrinsic metal in cells for cell concentration determination. The sample chamber was maintained at approximately $33{ }^{\circ} \mathrm{C}$ for all experiments. Transport efficiency (TE) measurement methods were evaluated by using $40 \mathrm{~nm}$ gold nanoparticles, yeast cells, and EQ four-element calibration beads. EQ fourelement calibration beads were then selected and used to measure TE before each experiment at 110,000 beads $/ \mathrm{mL}$ per vendor recommendation. Calibration curves consisted of $20 \mathrm{~nm}, 40 \mathrm{~nm}, 70 \mathrm{~nm}$, and $100 \mathrm{~nm}$ citrate-stabilized AgNPs at $\sim 10^{5} \mathrm{NPs} / \mathrm{mL}$.
Table 1 Optimized single-cell ICP-MS parameters

\begin{tabular}{|c|c|}
\hline Parameter & Value \\
\hline Manual sampling flow rate & $15-20 \mu \mathrm{L} / \mathrm{min}$ \\
\hline $\begin{array}{l}\text { Nebulizer } \\
\text { Spray chamber } \\
\text { Injector }\end{array}$ & $\begin{array}{l}\text { Meinhard TRP-90-A0.05 } \\
\text { Asperon Single-Cell } \\
\text { Quartz, } 2.0 \mathrm{~mm} \text { id }\end{array}$ \\
\hline $\begin{array}{l}\text { RF power } \\
\text { Nebulizer gas flow } \\
\text { Makeup gas flow } \\
\text { Analytes } \\
\text { Transport efficiency } \\
\text { Sample analysis time } \\
\text { Dwell time }\end{array}$ & $\begin{array}{l}1600 \mathrm{~W} \\
0.54 \mathrm{~L} / \mathrm{min} \\
0.7 \mathrm{~L} / \mathrm{min} \\
{ }^{64} \mathrm{Zn},{ }^{107} \mathrm{Ag} \\
30-40 \%^{\mathrm{a}} \\
100 \mathrm{~s} \\
50 \mu \mathrm{s}\end{array}$ \\
\hline $\begin{array}{l}\text { Sample loop size } \\
\text { Autosampler sample flow rate }\end{array}$ & $\begin{array}{l}100 \mu \mathrm{L} \\
15 \mu \mathrm{L} / \min \end{array}$ \\
\hline Sample vials ${ }^{\mathrm{b}}$ & $\begin{array}{l}\text { Micro96-well plate (poly- } \\
\text { propylene, } 2 \mathrm{~mL} \text { ) }\end{array}$ \\
\hline Carrier solution $^{\mathrm{b}}$ & $\mathrm{H}_{2} \mathrm{O}$ \\
\hline Working solution ${ }^{\mathrm{b}}$ & $\mathrm{H}_{2} \mathrm{O}$ \\
\hline Autosampler rinse $1^{\mathrm{b}}$ & $1 \% \mathrm{HNO}_{3}, 5 \% \mathrm{H}_{2} \mathrm{O}_{2}$ \\
\hline Autosampler rinse $2^{\mathrm{b}}$ & $\mathrm{H}_{2} \mathrm{O}$ \\
\hline
\end{tabular}

${ }^{\mathrm{a}}$ Measured daily or each batch of experiment

${ }^{\mathrm{b}}$ Autosampler-specific parameters

\section{Cellular exposure to AgNPs and SC-ICP-MS analysis}

Dosing with AgNPs was mainly conducted at $10^{7}$ cells/ $\mathrm{mL}$ concentration in $10 \mathrm{~mL}$ of dosing medium, unless otherwise noted in certain experiments. Dosing medium was $0.2 \%(\mathrm{w} / \mathrm{v})$ MES hydrate $+0.2 \%(\mathrm{w} / \mathrm{v})$ dextrose in ultrapure $\mathrm{H}_{2} \mathrm{O}$, adjusted to a pH of 6.8 using $\mathrm{NaOH}$. Different concentrations and sizes of AgNPs were added in this dosing medium. Each sample dosing level was prepared in triplicate. The samples were then capped and placed on a rotor for a specified exposure time (experiment dependent) at 12 rotations/min. The cell samples were then washed by following a published procedure [37] for three times by centrifugation (10 min first centrifugation, $5 \mathrm{~min}$ for second and third washes) at $500 \mathrm{~g}$ using $10 \mathrm{~mL}$ ultrapure $\mathrm{H}_{2} \mathrm{O}$ per wash in order to completely remove dosing medium and any residual-free floating silver nanoparticles. For experiments to remove surface-adsorbed AgNPs, the cell samples were washed with PBS buffer containing $20 \mathrm{mM} \mathrm{K}_{3} \mathrm{Fe}(\mathrm{CN})_{6}$ and $20 \mathrm{mM} \mathrm{Na} \mathrm{S}_{2} \mathrm{O}_{3} \cdot 5 \mathrm{H}_{2} \mathrm{O}$. This published procedure [47] that removes surface-adsorbed nanoparticles from human T-lymphocyte cells via a chemical etch process was validated to work for yeast cells in this study. After the washing step, the samples were resuspended in $1 \mathrm{~mL}$ of ultrapure $\mathrm{H}_{2} \mathrm{O}$. To completely remove any residual supernatant, each sample was transferred to a $1.5 \mathrm{~mL}$ centrifuge tube. Using a low-speed mini-centrifuge, the samples were centrifuged for about $20 \mathrm{~s}$, and then, the supernatant was removed. If needed, samples were placed in a refrigerator to save for 
analysis or continued for the next step of the analysis. The cells were resuspended in $1 \mathrm{~mL} \mathrm{H}_{2} \mathrm{O}$ and vortex-mixed for about $10 \mathrm{~s}$. This stock sample suspension was used to dilute to analysis concentrations $\left(\sim 10^{5}\right.$ cells $\left./ \mathrm{mL}\right)$ in $0.26 \mathrm{mM}$ EDTA aqueous solution in $15-\mathrm{mL}$ centrifuge tubes. Samples were vortex-mixed immediately before analysis by SC-ICPMS. Histograms were fitted using Syngistix Gaussian distribution, and the maximum of the distribution was utilized for result comparison. While the software directly reported Ag mass (ag) per cell, the particle number per cell was calculated by dividing the mass per cell by the mass of each AgNP.

\section{Transmission electron microscope imaging of AgNP-dosed yeast cells}

Transmission electron microscopy (TEM) was used to confirm the impact of the different washing processes and to check the status of AgNPs on the surface of the cells. The unstained AgNP-dosed yeast cells were deposited on TEM grids (Ted Pella, Inc. 300 mesh, Prod \# 01843-F), freshly glow discharged with a plasma cleaner for $3 \mathrm{~min}$, and left to incubate for $3 \mathrm{~min}$. Subsequently, excess sample suspension was gently wicked away from the grids with a filter paper, and the grids were air-dried at room temperature. A FEI Tecnai F20 transmission electron microscope (FEI, Hillsboro, OR, USA) was used for obtaining TEM images of dosed cells at an accelerating voltage of $200 \mathrm{kV}$.

\section{Results and discussion}

\section{SC-ICP-MS method optimization and performance}

Transport efficiency determination No universal TE detection standard method is currently reported for SC-ICP-MS analysis. We tested TE by three different methods to evaluate the accurate method for TE determination of yeast cells using the SC-ICP-MS analysis, as there have been several different methods reported with inconsistent results for TE detections of the SC-ICP-MS methods for algae cells [18,
19]. We first used the yeast cells themselves to determine TE by monitoring the intrinsic metal ${ }^{64} \mathrm{Zn}$, similar to the method used in a recently published paper [19]. $\mathrm{Zn}$ is present in high enough quantity in individual yeast cells to be detected by SC-ICP-MS. When we used the yeast cells in water to detect TE, a low TE (18\%) was obtained. EDTA has been reported to prevent cell aggregation $[19,48]$. By adding a small concentration of EDTA $(0.26 \mathrm{mM})$ to the final dilution of samples, the TE of the yeast cells increased to about $38 \%$ (Table 2). We also checked the cell integrities by collecting a sample post-nebulization and observing the cells using a microscope. The cells were intact after nebulization. EQ four-element beads in water at vendor-recommended concentrations $\left(1.1 \times 10^{5}\right.$ beads $\left./ \mathrm{mL}\right)$ were then tested to determine TE by monitoring the metal element ${ }^{140} \mathrm{Ce}$ in the beads. Since the beads are approximately $2.5 \mu \mathrm{m}$ in diameter, it has been considered in a previous study that they are more analogous to cells than nanoparticle suspensions due to their similar size and density [18]. The TE measured using the beads was found to be similar with the TE obtained by using the yeast cell suspension at the approximate concentration $1.0 \times 10^{5}$ cells $/ \mathrm{mL}$ in $0.26 \mathrm{mM}$ EDTA solution (Table 2). We also tested the TEs using $40 \mathrm{~nm}$ AuNP suspensions in water with and without EDTA. The TE from AuNP suspensions with EDTA was much higher (>90\%) than the TEs using yeast cells. The TE was also higher when the AuNPs were in water without EDTA, although better than that obtained by using the AuNPs with matrix-matched EDTA present. Our test results here did not agree well with other previously reported results where matrix-matched suspensions of AuNPs were utilized for TE determination [18]. Therefore, TE determination for the SC-ICP-MS analysis should be specific for the cell type and the matrix as part of method development. Though the most accurate method to determine TE should be the cells being analyzed, the TE determined by the beads for yeast cells in this study is similar or the same with those obtained by using yeast cells with EDTA present. Using the beads is a simpler way to determine TE compared with the cells because cells need to be freshly cultured and counted each time. Therefore, the EQ four-element beads were utilized for TE measurement (measured daily for each experiment) in this study.
Table 2 Transport efficiencies measured with yeast cell suspensions (intrinsic metal

${ }^{64} \mathrm{Zn}$ was monitored), EQ four-element calibration beads $\left({ }^{140} \mathrm{Ce}\right.$ in the beads was monitored), and Au NPs $\left({ }^{107} \mathrm{Au}\right.$ was monitored) in aqueous and matrix-matched solutions

\begin{tabular}{lll}
\hline Sample (matrix) & Concentration & $\begin{array}{l}\text { Transport } \\
\text { efficiency }(\%) \\
(n=3)\end{array}$ \\
\hline AuNPs (water) & $107,500($ particles $/ \mathrm{mL})$ & $47.13 \pm 0.98$ \\
AuNPs $(0.26 \mathrm{mM}$ EDTA in water) & $107,500(\text { particles } / \mathrm{mL})_{-}$ & $96.85 \pm 2.12$ \\
EQ four-element beads (water) & $1.1 \times 10^{5}(\text { beads } / \mathrm{mL})_{-}$ & $42.06 \pm 2.60$ \\
Yeast cells (water) & $10^{5}(\text { cells } / \mathrm{mL})_{-}$ & $18.35 \pm 0.81$ \\
Yeast cells $(0.26 \mathrm{mM}$ EDTA in water) & $10^{5}(\text { cells } / \mathrm{mL})_{-}$ & $38.04 \pm 5.49$ \\
\hline
\end{tabular}


Reproducibility and stability The stability of yeast cell TEs over $9 \mathrm{~h}$ with measurements taken every $1.5 \mathrm{~h}$ with hemacytometer-counted cell suspensions was found to be acceptable at $44.2 \pm 2.8 \%$. Reproducibility of the method was tested through an experiment where 3 separate cell cultures were grown from 3 different colonies. Each colony was dosed with 10, 20, and $40 \mathrm{~nm}$ AgNPs at 3000, 1000, and $300 \mathrm{AgNPs} / \mathrm{cell}$, respectively, for approximately $3 \mathrm{~h}$. The $\%$ RSDs of the maximum of the Gaussian distributions were less than $6 \%$ for the same cell culture $(n=3)$ across all three AgNP sizes tested. The \%RSDs of results from all three cells cultures $(n=9)$ were less than $8 \%$ for all three AgNP sizes tested (Fig. S3).

While ag Ag/cell results were generally Gaussian, the fitting to the maximum of the cell distribution using the Gaussian fit software setting obtained highly repeatable results with an \%RSD of $5.3 \%(n=3)$ (Fig. 1).

Linear correlation and detection limits Yeast cell concentrations were measured at a concentration range from 1000 to $1,000,000$ cells/mL by both the SC-ICP-MS method and by counting the cells with a hemacytometer. It should be noted that only the stock cell suspension was counted by hemacytometer, and the lower concentrations were calculated from the different dilutions because this counting method is not accurate for counting low concentrations of cells. It showed good linear correlation from $1,000,000$ cells $/ \mathrm{mL}$ down to 1000 cells $/ \mathrm{mL}$ (Fig. 2). Therefore, the cell concentration detection limit was estimated to be 1000 cells $/ \mathrm{mL}$. While not specifically evaluated in this study, this detection limit could theoretically be improved with longer analysis time. The mass detection limit of $\mathrm{Ag}$ per cell for AgNPs was based on AgNP calibration curves (10, 20, 40, 70, $100 \mathrm{~nm})$ collected from multiple experiments, and representative detection limits were calculated using the ICH guidelines [49].

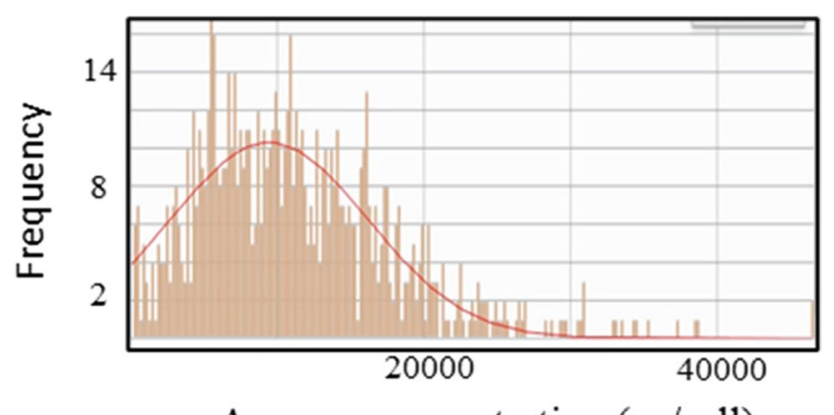

Ag mass concentration (ag/cell)

Fig. 1 Gaussian distribution fitting of representative histogram for AgNP-dosed yeast cells. Dosed $2300 \mathrm{AgNPs} / \mathrm{cell}, \mathrm{AgNP}$ size is $10 \mathrm{~nm}$

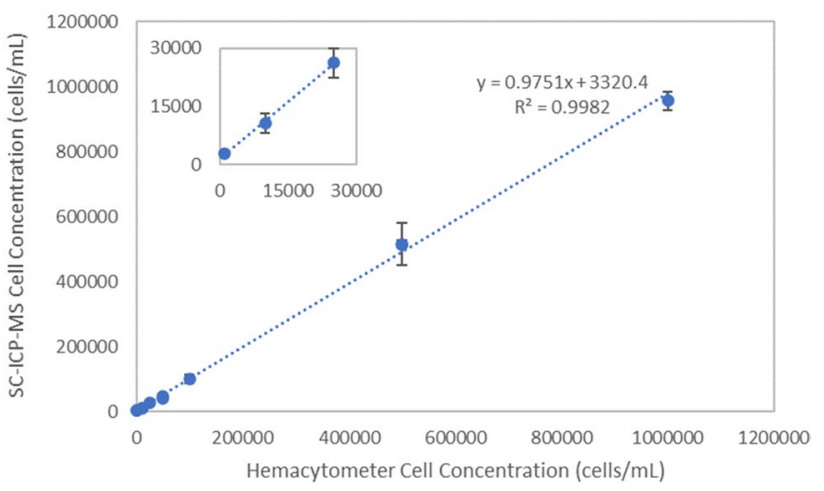

Fig. 2 Cell concentrations detected by SC-ICP-MS versus hemacytometer-counted cell concentrations tested on 2 different days. Concentration of cell stock suspension was determined with hemacytometer, and then diluted samples were prepared for analysis. Error bars represent standard deviation $(n=6)$

$\mathrm{DL}=\frac{3.3(\sigma)}{\text { slopeofcalibrationcurve }}$

where $\sigma=$ standard deviation of the $y$-intercepts for the AgNP calibration curve, and DL is the mass detection limit (ag Ag/cell).

The silver detection limit was approximately $78 \mathrm{ag} / \mathrm{cell}$. For smaller nanoparticles (10 and $20 \mathrm{~nm}$ ) below or near the detection limit, it was necessary for multiple nanoparticles to be present on or in the cell for the cell to be detected by the SC-ICP-MS when monitoring the analyte ${ }^{107} \mathrm{Ag}$. Therefore, the detection limit was equivalent to approximately 14 of $10 \mathrm{~nm}$ and 2 of $20 \mathrm{~nm} \mathrm{AgNPs/cell.}$

\section{Washing methods and their impacts on AgNP and yeast cell interactions}

The SC-ICP-MS method cannot distinguish if the AgNPs were in the cells or attached on the surface of the cells. Therefore, cells were imaged using TEM post-dosing with AgNPs to validate the presence of AgNPs on the cell surfaces. Two washing processes were evaluated: (1) wash with ultrapure water, which leaves the cell surface-adsorbed AgNPs intact, and (2) wash by PBS buffer containing $20 \mathrm{mM} \mathrm{K}{ }_{3} \mathrm{Fe}(\mathrm{CN})_{6}$ and $20 \mathrm{mM} \mathrm{Na}_{2} \mathrm{~S}_{2} \mathrm{O}_{3} \cdot 5 \mathrm{H}_{2} \mathrm{O}$ to remove the cell surface-adsorbed AgNPs. The procedure for removal of surface-adsorbed nanoparticles from human T-lymphocyte cells is a previously published protocol by Ivask, A, et al. [24, 47], but this procedure has not been used on yeast cells, a microorganism. Therefore, the washing efficiencies by water and the buffer (PBS solution with $20 \mathrm{mM} \mathrm{K}{ }_{3} \mathrm{Fe}(\mathrm{CN})_{6}$ and $\left.\mathrm{Na}_{2} \mathrm{~S}_{2} \mathrm{O}_{3} \cdot 5 \mathrm{H}_{2} \mathrm{O}\right)$ were evaluated by SC-ICP-MS (Table 3 ). The washing impacts were evaluated after 1,3 , and 6 washes with $\mathrm{H}_{2} \mathrm{O}$, and no 
Table 3 Quantitative comparison of cell surfaceadsorbed and intracellular AgNPs. Dosed concentration ratio was $2300 \mathrm{AgNPs} /$ cell and dosing time was $24 \mathrm{~h}, n=3$

\begin{tabular}{llllll}
\hline $\begin{array}{l}\text { AgNP } \\
\text { size }(\mathrm{nm})\end{array}$ & $\begin{array}{l}\text { AgNP loca- } \\
\text { tion on cell }\end{array}$ & ag Ag/cell (\%RSD) & AgNPs/cell (\%RSD) & $\%$ uptake & $\begin{array}{l}\% \\
\text { Intracellular:surface- } \\
\text { adsorbed AgNPs }\end{array}$ \\
\hline 10 & Total & $8903(5.1)$ & $1621(5.1)$ & 70.5 & - \\
10 & Internal & $6359(1.8)$ & $1158(1.8)$ & 50.3 & 71.4 \\
10 & External & 2544 & 463 & 20.1 & 28.6 \\
20 & Total & $15,603(2.2)$ & $355(2.3)$ & 15.4 & - \\
20 & Internal & $11,592(4.3)$ & $264(4.2)$ & 11.5 & 74.3 \\
20 & External & 4011 & 91 & 4.0 & 25.7 \\
\hline
\end{tabular}

significant effects were observed, indicating that AgNPs loosely attached outside of the cell wall were washed off completely by 3 water washes, and successive washes had no further impact on the total AgNPs associated with yeast cells (Fig. S1). Therefore, three-time water wash procedure was used for the determination of total AgNP associated with cells after yeast cell exposure to AgNPs prior to the SC-ICP-MS analysis. When AgNP-dosed cells were washed by $\mathrm{PBS}$ containing $\mathrm{K}_{3} \mathrm{Fe}(\mathrm{CN})_{6}$ and $\mathrm{Na}_{2} \mathrm{~S}_{2} \mathrm{O}_{3} \cdot 5 \mathrm{H}_{2} \mathrm{O}$ for 3 times, the AgNPs adsorbed to the surface of the cells were removed and the AgNP concentration per cell decreased compared with those by water wash. The results from different washes were also confirmed by the TEM. The representative TEM images are shown in Fig. S2. No AgNPs were present for the blank control (Figure S2A, no AgNP-dosed). There were many AgNPs associated with the cell surface after 3-time water wash (Figure S2B). The cell surface-adsorbed AgNPs were completely removed from the cell surface after washing 3 times by the PBS buffer containing $\mathrm{K}_{3} \mathrm{Fe}(\mathrm{CN})_{6}$ and $\mathrm{Na}_{2} \mathrm{~S}_{2} \mathrm{O}_{3} \cdot 5 \mathrm{H}_{2} \mathrm{O}$ (Figure $\mathrm{S} 2 \mathrm{C}$ ). Our results are in agreement with published literature showing that AgNPs are adsorbed to the cell wall due to attraction to various functional groups on the cell wall [44]. The insides of cells were not imaged, but prior literature has shown uptake of AgNPs internally in S. cerevisiae was kept as nanoparticles. Therefore, for all calculations in this study, it was assumed that any silver taken up by yeast cells and detected by SC-ICP-MS was AgNPs [44]. For samples washed with $\mathrm{H}_{2} \mathrm{O}$, SC-ICP-MS results represent the total AgNPs associated with cells, including AgNPs adsorbed to the cell surfaces and the AgNPs inside the cells. For those washed with PBS buffer containing $\mathrm{K}_{3} \mathrm{Fe}(\mathrm{CN})_{6}$ and $\mathrm{Na}_{2} \mathrm{~S}_{2} \mathrm{O}_{3} \cdot 5 \mathrm{H}_{2} \mathrm{O}$, SC-ICP-MS results represent only the intracellular AgNPs. One key advantage of this novel SC-ICP-MS method is the accurate quantification of AgNPs inside the yeast cells, the total AgNP associated with the cell, and adsorbed onto the cell surface by calculation. Another major advantage is that it can determine the AgNPs in individual cells and the distribution profile in the cell population as shown in histograms (Fig. 1).

\section{Dosing time impact on AgNP uptake}

To determine the effect of dose time on AgNP uptake, cells were dosed with $10 \mathrm{~nm}$ AgNPs at a concentration ratio of $1820 \mathrm{AgNPs} / \mathrm{cell}$ and tested at various intervals over the course of $48 \mathrm{~h}$ (Fig. 3). The majority of the $10 \mathrm{~nm} \mathrm{AgNP}$ uptake took place in the first hour, with only slight additional uptake with increasing exposure time up to $48 \mathrm{~h}$. This indicated the fast uptake kinetics of the AgNPs by the yeast cells. It should be noted that we did not collect data shorter than $1 \mathrm{~h}$, and thus could not derive the kinetics constant of the uptake, though the SC-ICP-MS is a potential method to study uptake kinetics. Further study may be conducted to estimate the uptake kinetics using this SC-ICP-MS method.

\section{Uptake efficiencies by different sizes of AgNPs at different dosing concentrations}

The experiment was conducted to evaluate the correlation of AgNP uptake vs dosing concentration. The correlation of AgNP uptake presented by mass of each cell (ag/cell) vs dosing mass concentration of AgNP (ag/cell) in cell culture is shown in Fig. 4. Amounts of uptake by each cell increased quickly with increased AgNP dosing concentration when the dosing concentrations were low. The uptake increasing

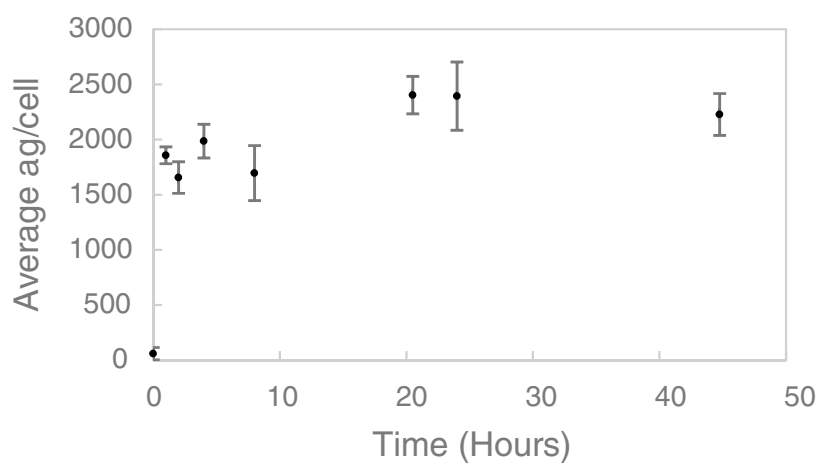

Fig. 3 Cellular uptake of $10 \mathrm{~nm}$ AgNPs vs exposure time. Dosed concentration ratio was $9997 \mathrm{ag}$ Ag/cell (1820 Ag NPs/cell) concentration ratio. The error bars represent standard deviation $(n=3)$ 


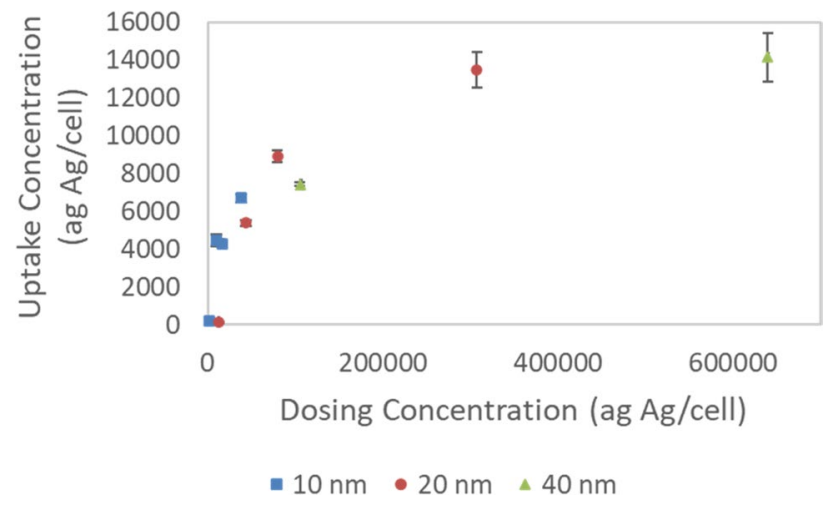

Fig. 4 Uptake concentration versus dosing concentration ag $\mathrm{Ag} / \mathrm{cell}$ for different sizes of AgNPs. Dosing time is about $3 \mathrm{~h}$. The error bars represent standard deviation $(n=3)$

slowed down when dosing AgNP concentrations were further increased. It seems that the uptake was driven by mass of Ag per cell where similar mass uptakes per cell were observed for all three AgNPs sizes. However, when the correlation of uptake vs dosing concentration was expressed in terms of particle concentration of AgNPs per cell, differences were observed for different AgNP sizes. The AgNP uptake particle concentration per cell increased with increasing dosing AgNP particle concentration per cell (Fig. 5 top), while the uptake percentage of the AgNPs showed a clear optimum dosing concentration for each nanoparticle size tested (Fig. 5 bottom). Under these experimental conditions, the highest percentage uptakes were dosing concentrations at approximately 1820, 1000, and $300 \mathrm{AgNPs} /$ cell for 10, 20, and $40 \mathrm{~nm}$ AgNPs, respectively.

\section{Internal uptake versus cell surface-adsorbed AgNP}

Cells were dosed with a concentration ratio of $2300 \mathrm{AgNPs}$ per cell for $24 \mathrm{~h}$ to allow enough time for uptake of the AgNPs. Uptakes of $10 \mathrm{~nm}$ and $20 \mathrm{~nm}$ AgNPs were tested. Six samples of the same dosing particle concentrations were prepared for each AgNP size. Three samples were washed with $\mathrm{H}_{2} \mathrm{O}$ and the other three were washed with PBS containing $20 \mathrm{mM} \mathrm{K}_{3} \mathrm{Fe}(\mathrm{CN})_{6}$ and $\mathrm{Na}_{2} \mathrm{~S}_{2} \mathrm{O}_{3} \cdot 5 \mathrm{H}_{2} \mathrm{O}$ to distinguish between surface-adsorbed and intracellular AgNPs. The samples were then analyzed by the SC-ICP-MS method and results were used to calculate the total, intracellular, and surface adsorbed AgNPs (Table 3). The total uptake for $10 \mathrm{~nm}$ AgNP (1621 particles/cell) was much higher than those for $20 \mathrm{~nm}$ AgNP (355 particles/cell), about 4.6 times, based on the particle concentration (particles/cell). However, the total mass uptake of $10 \mathrm{~nm} \mathrm{AgNP} \mathrm{(8903} \mathrm{ag/cell)} \mathrm{was} \mathrm{lower} \mathrm{than}$ those for $20 \mathrm{~nm} \operatorname{AgNP}(15,603 \mathrm{ag} / \mathrm{cell})$, about 0.57 times, based on the mass concentration (ag/cell). Interestingly, despite the differences in nanoparticle size, the proportions by mass of intracellular and surface-adsorbed AgNPs were similar for both the $10-\mathrm{nm}$ and 20 -nm sizes analyzed, at $71.4 \%$ intracellular and $28.6 \%$ on the cell surface for $10 \mathrm{~nm}$ AgNPs, and at $74.3 \%$ intracellular and $25.7 \%$ on the cell surface for $20 \mathrm{~nm} \mathrm{AgNPs}$. These results suggested that the

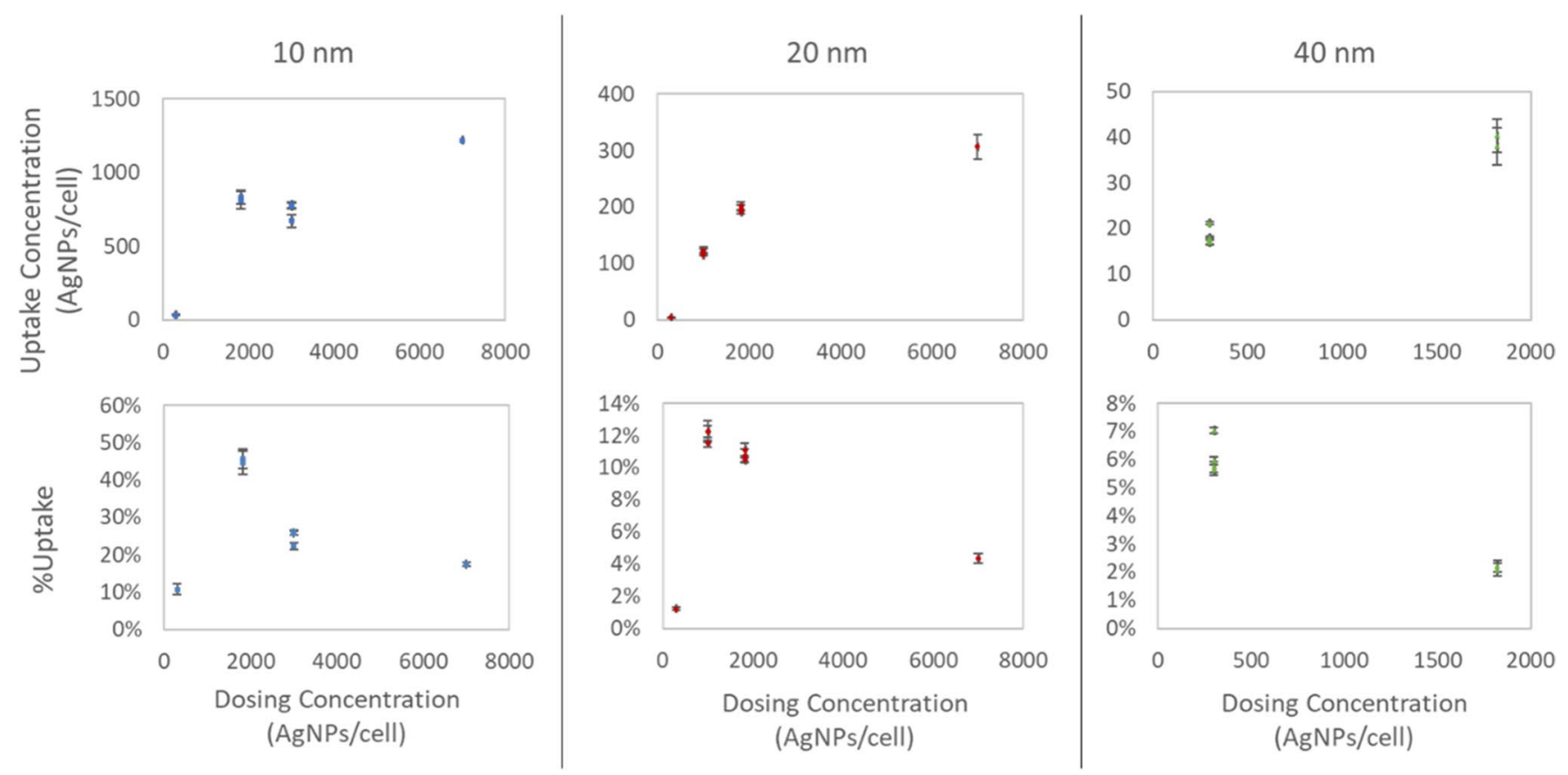

Fig. 5 Uptake concentrations and \%uptake versus dosing particle concentrations. Dosing time is about $3 \mathrm{~h}$. The error bars represent standard deviation $(n=3)$ 
ratio of the cell surface-adsorbed AgNPs and intracellular AgNPs is likely biologically regulated by the mass of the AgNPs, not by the size of the AgNPs. However, more experiments to see if this ratio stays constant or is affected by other variables such as dose time, dose concentration, and NP size would be of interest. This experiment shows that the method works well for quantitatively evaluating intracellular versus surface-adsorbed AgNPs. This could be a useful method for applications in the growing research area of green synthesis of AgNPs where optimal AgNPs per cell can be quantitatively evaluated quickly using the SC-ICPMS technique [36-38].

Overall, this new SC-ICP-MS method was able to quantitate the uptake of AgNPs by yeast cells both adsorbed to the cell surface and located intracellularly. While AgNPs have been reported to be toxic to yeast cells [41], the cell integrity was found to remain intact during the dosing times and concentrations tested in this study, even at the high AgNP dosing concentrations of several thousand AgNPs per cell. Since the SC-ICP-MS can rapidly quantify the cell concentration, silver concentration, and profile of the nanoparticle distribution in a cell population, this makes it a potential asset for green manufacturing applications for the AgNP synthesis using yeast cells where optimal yields per cell can be quickly optimized and evaluated. This new SC-ICP-MS method also can be utilized as a complementary method for nanotoxicity studies, which commonly utilize $S$. cerevisiae as a model [39-41], by quantitatively monitoring the nanoparticle-cell interactions, fate of nanoparticles, and viability of the cells (pulse signals of the cells will change when cells lyse after death).

\section{Conclusions}

A new SC-ICP-MS method was developed for evaluating AgNP interactions with yeast cells as a model. Different TE determination methods were evaluated and the results showed that $40 \mathrm{~nm}$ AuNPs were not suitable for TE detection for SC-ICP-MS analysis of yeast cells. Yeast cells in EDTA aqueous solution resulted in similar TEs with the commercial EQ four-element beads, and the beads were used for the daily TE measurement in this study. This SC-ICP-MS method can not only rapidly quantify the cell concentration, silver concentration per cell, and profile of nanoparticle distribution in a cell population, but also quantitatively distinguish the amount of cell surface-adsorbed AgNPs and intracellular AgNPs by washing the dosed yeast cells using a water wash and PBS solution wash (with $20 \mathrm{mM}$ $\mathrm{K}_{3} \mathrm{Fe}(\mathrm{CN})_{6}$ and $\mathrm{Na}_{2} \mathrm{~S}_{2} \mathrm{O}_{3} \cdot 5 \mathrm{H}_{2} \mathrm{O}$ ), demonstrating, for the first time, a previously published method used for mammalian cells (human T-lymphocyte cells) [24, 47] which can be applied to remove the cell wall-adsorbed AgNPs from $S$. cerevisiae cells, a microorganism of the fungus kingdom, while leaving the cells intact for analysis. The yeast cell AgNP uptake study demonstrated that the initial uptake of AgNPs was rapid and primarily driven by the mass of Ag per cell, not the nanoparticle size. However, there were optimal dosing concentrations in terms of AgNP particles per cell for each nanoparticle size tested. This model and metrology have high potential to be utilized in many applications, especially for green synthesis method optimization and as a complementary method for nanotoxicity studies. To the authors' best knowledge, this is the first report for quantifying AgNP uptake in S. cerevisiae using SC-ICP-MS methodology.

Supplementary Information The online version contains supplementary material available at https://doi.org/10.1007/s00216-022-03937-4.

Acknowledgements This work was supported by Perkin Elmer, Inc., and the Center for Single Nanoparticle, Single Cell, and Single Molecule Monitoring $\left(\mathrm{CS}^{3} \mathrm{M}\right)$ at Missouri University of Science and Technology. The authors acknowledge the contributions from the following individuals over the course of this project: Chady Stephan and Jack Quade for assisting and training operators on SC-ICP-MS setup and operation, $\mathrm{Ke} \mathrm{Li}$ for assisting cell culture procedures used in the project, and Alec Falkenhain and Xing Shen for helping with some preliminary experiments at the early stage of the project.

Author contribution All authors contributed to the study conception and design. All authors commented on previous versions of the manuscript. LR conducted experiments and wrote the first draft of the manuscript. WL conducted TEM imaging tests and advised on ICP-MS operation. KS supervised the yeast cell culture and edited the manuscript. HS conceived and designed the research, analyzed the data, and prepared the paper together with LR. All authors read and approved the final version of the manuscript.

Funding This study was funded by Perkin Elmer, Inc., and the Center for Single Nanoparticle, Single Cell, and Single Molecule Monitoring.

Availability of data and material The data used in this study are available from the corresponding author upon reasonable request.

Code availability Not applicable.

\section{Declarations}

Ethics approval This article does not contain any studies with human and/or animal participants.

Consent to participate Not applicable.

Conflict of interest The authors declare no competing interests.

\section{References}

1. Taghavi SM, Momenpour M, Azarian M, Ahmadian M, Souri F, Taghavi SA, et al. Effects of nanoparticles on the environment and outdoor workplaces. Electron Physician. 2013;5(4):706-12. 
2. Ramos AP, Cruz MAE, Tovani CB, Ciancaglini P. Biomedical applications of nanotechnology. Biophys Rev. 2017;9(2):79-89.

3. Abdelbasir SM, McCourt KM, Lee CM, Vanegas DC. Wastederived nanoparticles: synthesis approaches, environmental applications, and sustainability considerations. Front Chem. 2020;8:782.

4. Lu J, Struewing I, Buse HY, Kou J, Shuman HA, Faucher SP, et al. Legionella pneumophila transcriptional response following exposure to $\mathrm{CuO}$ nanoparticles. Appl Environ Microbiol. 2013;79(8):2713-20.

5. Bondarenko O, Juganson K, Ivask A, Kasemets K, Mortimer M, Kahru A. Toxicity of $\mathrm{Ag}, \mathrm{CuO}$ and $\mathrm{ZnO}$ nanoparticles to selected environmentally relevant test organisms and mammalian cells in vitro: a critical review. Arch Toxicol. 2013;87:1181-200.

6. Hulkoti NI, Taranath TC. Biosynthesis of nanoparticles using microbes-a review. Colloids Surf, B. 2014;121:474-83.

7. Ahmed S, Ahmad M, Swami BL, Ikram S. A review on plants extract mediated synthesis of silver nanoparticles for antimicrobial applications: a green expertise. J Adv Res. 2016;7(1):17-28.

8. Hoseinzadeh E, Makhdoumi P, Taha P, Hossini H, Pirsaheb $\mathrm{M}$, OmidRastegar $\mathrm{S}$, et al. A review of available techniques for determination of nano-antimicrobials activity. Toxin Reviews. 2017;36(1):18-32.

9. Kettler K, Krystek P, Giannakou C, Hendriks AJ, de Jong WH. Exploring the effect of silver nanoparticle size and medium composition on uptake into pulmonary epithelial 16HBE14o-cells. J Nanopart Res. 2016;18:182.

10. Wilhelm S, Tavares AJ, Dai Q, Ohta S, Audet J, Dvorak HF, et al. Analysis of nanoparticle delivery to tumours. Nat Rev Mater. 2016;1(5):16014.

11 Sharma A, Kontodimas K, Bosmann M. Nanomedicine: a diagnostic and therapeutic approach to COVID-19. Front Med (Lausanne). 2021;8:648005.

12. Yang D. Application of nanotechnology in the COVID-19 pandemic. Int J Nanomed. 2021;16:623-49.

13. Ashraf S, Hassan Said A, Hartmann R, Assmann MA, Feliu $\mathrm{N}$, Lenz $\mathrm{P}$, et al. Quantitative particle uptake by cells as analyzed by different methods. Angew Chem Int Ed Engl. 2020;59(14):5438-53.

14. FitzGerald LI, Johnston APR. It's what's on the inside that counts: techniques for investigating the uptake and recycling of nanoparticles and proteins in cells. J Colloid Interface Sci. 2021;587:64-78.

15. Despax B, Saulou C, Raynaud P, Datas L, Mercier-Bonin M. Transmission electron microscopy for elucidating the impact of silver-based treatments (ionic silver versus nanosilver-containing coating) on the model yeast Saccharomyces cerevisiae. Nanotechnology. 2011;22(17):175101.

16. Mueller L, Traub H, Jakubowski N, Drescher D, Baranov VI, Kneipp J. Trends in single-cell analysis by use of ICP-MS. Anal Bioanal Chem. 2014;406(27):6963-77.

17. Wang H, Wang M, Wang B, Zheng L, Chen H, Chai Z, et al. Interrogating the variation of element masses and distribution patterns in single cells using ICP-MS with a high efficiency cell introduction system. Anal Bioanal Chem. 2017;409(5):1415-23.

18. Merrifield RC, Stephan C, Lead JR. Quantification of Au nanoparticle biouptake and distribution to freshwater algae using single cell - ICP-MS. Environ Sci Technol. 2018;52:2271-7.

19. Shen X, Zhang H, He X, Shi H, Stephan C, Jiang H, et al. Evaluating the treatment effectiveness of copper-based algaecides on toxic algae Microcystis aeruginosa using single cell-inductively coupled plasma-mass spectrometry. Anal Bioanal Chem. 2019;411(21):5531-43.

20. Ho K-S, Chan W-T. Time-resolved ICP-MS measurement for single-cell analysis and on-line cytometry. J Anal At Spectrom. 2010;25:1114-22.
21. Zheng L-N, Wang M, Wang B, Chen H-Q, Ouyang H, Zhao Y-L, et al. Determination of quantum dots in single cells by inductively coupled plasma mass spectrometry. Talanta. 2013;116:782-7.

22. Meyer S, López-Serrano A, Mitze H, Jakubowski N, Schwerdtle T. Single-cell analysis by ICP-MS/MS as a fast tool for cellular bioavailability studies of arsenite. Metallomics. 2018;10(1):73-6.

23. Virani F, Tanner S. Mass cytometry: an evolution in ICP-MS enabling novel insights in single-cell biology. Spectroscopy. 2015;30(5):14-22.

24. Malysheva A, Ivask A, Doolette CL, Voelcker NH, Lombi E. Cellular binding, uptake and biotransformation of silver nanoparticles in human T lymphocytes. Nat Nanotechnol. 2021;16(8):926-32.

25. Drescher D, Giesen C, Traub H, Panne U, Kneipp J, Jakubowski N. Quantitative imaging of gold and silver nanoparticles in single eukaryotic cells by laser ablation ICP-MS. Anal Chem. 2012;84:9684-8.

26. Wang M, Zheng L-N, Wang B, Chen H-Q, Zhao Y-L, Chai Z-F, et al. Quantitative analysis of gold nanoparticles in single cells by laser ablation inductively coupled plasma-mass spectrometry. Anal Chem. 2014;86:10252-6.

27. Zhai J, Wang Y, Xu C, Zheng L, Wang M, Feng W, et al. Facile approach to observe and quantify the $\alpha \operatorname{IIb} \beta 3$ integrin on a singlecell. Anal Chem. 2015;87:2546-9.

28. Van Malderen SJM, Vergucht E, De Rijcke M, Janssen C, Vincze L, Vanhaecke F. Quantitative determination and subcellular imaging of $\mathrm{Cu}$ in single cells via laser ablation-ICP-mass spectrometry using high-density microarray gelatin standards. Anal Chem. 2016;88:5783-9.

29. Wang H, Chen B, He M, Hu B. A Facile droplet-chip-timeresolved inductively coupled plasma mass spectrometry online system for determination of zinc in single cell. Anal Chem. 2017;89:4931-8.

30. Hong A, Tang Q, Khan AU, Miao M, Xu Z, Dang F, et al. Identification and speciation of nanoscale silver in complex solid matrices by sequential extraction coupled with inductively coupled plasma optical emission spectrometry. Anal Chem. 2021;93(4):1962-8.

31. Miyashita S-i, Fujii S-i, Shigeta K, Inagaki K. Single cell analysis by using ICP-MS. Metallomics 2017. p. 107-24.

32. Corte-Rodríguez M, Álvarez-Fernández R, García-Cancela P, Montes-Bayón M, Bettmer J. Single cell ICP-MS using on line sample introduction systems: current developments and remaining challenges. TrAC Trends Anal Chem. 2020;132:116042.

33. Wei X, Lu Y, Zhang X, Chen M-L, Wang J-H. Recent advances in single-cell ultra-trace analysis. TrAC Trends Anal Chem. 2020;127:115886.

34 Yin L, Zhang Z, Liu Y, Gao Y, Gu J. Recent advances in singlecell analysis by mass spectrometry. Analyst. 2019;144(3):824-45.

35. Yu X, He M, Chen B, Hu B. Recent advances in single-cell analysis by inductively coupled plasma-mass spectrometry: a review. Anal Chim Acta. 2020;1137:191-207.

36. Badhusha MSM, Mohideen MMAK. Biosynthesis of silver nanoparticles using Saccharomyces cerevisiae with different $\mathrm{pH}$ and study of antimicrobial activity against bacterial pathogens. Chem Sci Trans. 2016;5(4):906-11.

37. Chen Z, Li Z, Chen G, Zhu J, Liu Q, Feng T. In situ formation of AgNPs on S. cerevisiae surface as bionanocomposites for bacteria killing and heavy metal removal. Int J Environ Sci Technol. 2017;14:1635-42.

38. Li J, Ma G, Liu H, Liu H. Yeast cells carrying metal nanoparticles. Mater Chem Phys. 2018;207:373-9.

39. Narollahi A, Pourshamsian K, Mansourkiaee P. Antifungal activity of silver nanoparticles on some of fungi. Int J Nano Dimens. 2011;1(3):233-9.

40. Sillapawattana $\mathrm{P}$, Gruhlke $\mathrm{MCHH}$, Schäffer A. Effect of silver nanoparticles on the standard soil arthropod Folsomia candida 
(Collembola) and the eukaryote model organism Saccharomyces cerevisiae. Environ Sci Eur. 2016;28(1):27.

41. Zhang W, Liu X, Bao S, Xiao B, Fang T. Evaluation of nano-specific toxicity of zinc oxide, copper oxide, and silver nanoparticles through toxic ratio. J Nanopart Res. 2016;18(12):372.

42. Sujith A, Itoh T, Abe H, Anas AA, Yoshida K, Biju V, et al. Surface enhanced Raman scattering analyses of individual silver nanoaggregates on living single yeast cell wall. Appl Phys Lett. 2008;92:103901.

43. Sujith A, Itoh T, Abe H, Yoshida K-i, Kiran MS, Biju V, et al. Imaging the cell wall of living single yeast cells using surface-enhanced Raman spectroscopy. Anal Bioanal Chem. 2009;394:1803-9.

44. Bayat N, Rajapakse K, Marinsek-Logar R, Drobne D, Cristobal $\mathrm{S}$. The effects of engineered nanoparticles on the cellular structure and growth of Saccharomyces cerevisiae. Nanotoxicology. 2014;8(4):363-73.

45. Bahadar H, Maqbool F, Niaz K, Abdollahi M. Toxicity of nanoparticles and an overview of current experimental models. Iran Biomed J. 2016;20(1):1-11.
46. Kettler K, Veltman K, van de Meent D, van Wezel A, Hendriks AJ. Cellular uptake of nanoparticles as determined by particle properties, experimental conditions, and cell type. Environ Toxicol Chem. 2014;33(3):481-92.

47. Ivask A, Mitchell AJ, Hope CM, Barry SC, Lombi E, Voelcker NH. Single cell level quantification of nanoparticle-cell interactions using mass cytometry. Anal Chem. 2017;89:8228-32.

48. Cossarizza A, Chang HD, Radbruch A, Acs A, Adam D, AdamKlages S, et al. Guidelines for the use of flow cytometry and cell sorting in immunological studies (second edition). Eur J Immunol. 2019;49(10):1457-973.

49. Validation of analytical procedures: text and methodology [updated November 1, 2005; cited 2021 November 2]. Available from: https://www.ich.org/page/quality-guidelines.

Publisher's note Springer Nature remains neutral with regard to jurisdictional claims in published maps and institutional affiliations. 